\title{
Relationship between National Culture and Safety Behaviour: Evidence from Petrochemical Employees in Saudi Arabia
}

\author{
Ayedh Alshahrani ${ }^{1}$, Kriengsak Panuwatwanich ${ }^{2}$, and Sherif Mohamed ${ }^{3}$
}

\begin{abstract}
Saudi Arabia relies heavily on its petroleum-related industries, including petrochemicals and refining, which are undoubtedly the lifeblood for the Saudi economy. Given major petrochemical accidents can be catastrophic, with significant emotional and economic impacts on businesses, families, and societies, safety management within the industry is paramount. Petrochemical industry in Saudi Arabia is a multinational company operating in 40 countries with over 40,000 employees. In any workforce, ignoring cultural differences is a serious cause of misunderstandings and, as a result and conflict. Moreover, safety behaviour is considered as the foundation of underlying safety activities that must be established by employees permitting the occupational, safety and health requirements to circumvent accidents at workplace. Within the current body of knowledge, empirical studies on the impact of national culture on safety attitudes, behaviour and performance seem to be limited. This paper presents a research study aiming to examine the relationship between national culture and safety behaviour within the context of petrochemical industry. The study surveyed 407 petrochemical employees in Saudi Arabia and uncovered a significant difference between the perceptions of Saudi and non-Saudi employees across Hofstede's cultural dimensions. The study also revealed how these cultural dimensions are associated with the safety behaviour of both the Saudi and non-Saudi sample groups.
\end{abstract}

Keywords: National culture, petrochemical, safety behaviour, Saudi Arabia.

\section{Introduction}

Organisations seek to reduce occupational accidents because of their emotional and economic impact on businesses, families, and societies. Results from several studies support the notion that the majority of occupational accidents are caused by people rather than unsafe working environments. In the past, industrial accidents were described mainly in terms of technological errors, while the human factors that caused the accidents tended to be ignored (Gordon 1998). Since the frequency of technological failures have been reduced, the role of human factors has become more prominent (Gordon 1998).

Accidents in a highly complex socio-technical system are dependent upon the interaction of technical, human, social, organisational, managerial, and environmental factors. These factors could all be contributors to accidents (Cullen 1980). Human factors were considered to be the root cause of accidents by psychologists, reliability engineers and human factors specialists (Wilpert 1995). For this reason, safety professionals should pay attention to employee's behaviour as a root cause, in order to develop preventive measures that reduce undesired outcomes.

\footnotetext{
${ }^{1} \mathrm{PhD}$ candidate, Griffith School of Engineering, Griffith University, Gold Coast campus, Queensland, Australia 4222, Tel: +617-5552-9057, E-mail: a.alshahrani@griffith.edu.au

${ }^{2}$ Senior Lecturer, Griffith School of Engineering, Griffith University, Gold Coast campus, Queensland, Australia 4222, Tel: +617-5552-7357, E-mail: k.panuwatwanich@griffith.edu.au

${ }^{3}$ Professor, Griffith School of Engineering, Griffith University, Gold Coast campus, Queensland, Australia 4222, Tel: +617-5552-8575, E-mail: k.panuwatwanich@griffith.edu.au
} 
In any workforce, ignoring cultural differences is a serious cause of misunderstandings and, as a result, conflict (Finestone \& Snyman 2005). All organisations function within a national cultural context, irrespective of whether that context is defined in terms of shared meanings, values and assumptions or observable rites and rituals (Burke, Chan-Serafin, Salvador, Smith \& Sarpy 2008). It is important to consider safety issues in the context of different cultural backgrounds. This study intends to address the following research questions, within the context of the petrochemical industry in Saudi Arabia:

- What are the national culture dimensions that influence safety behaviour?

- How to develop the strategies or guidelines for the improvement of workplace safe behaviour by considering national culture dimensions.

\section{Theoretical Background}

\section{National Culture}

The term 'national culture' is determined by the belief that each country has people with a shared history and experiences - a homogeneous culture which is the basis for the national culture (Bhaskaran \& Gligorovska 2009). According to Hofstede (1980), national culture is defined as "the collective programming of the mind which distinguishes the members of one human group from another". To study the cultural influence on societies, one needs typologies (Schein 1985) or dimensions (Hofstede 1980) that can be used to analyse the behaviour, actions and values of the members of a society. The most replicated and cited dimensions in cross-cultural research is Hofstede (1980) framework. This study revealed four cultural dimensions: (1) the Power Distance Index (PDI); (2) the Individualism Index (IDV); (3) the Masculinity Index (MAS); and (4) the Uncertainty Avoidance Index (UAI). In 1991, a fifth dimension was identified after Hofstede and Bond (1988) worked together on a survey known as the Chinese Values Survey. The fifth dimension was the Long Term Orientation Index (LTO) (Hofstede 2001). Hofstede, Hofstede, Minkov and Vinken (2008) found two new cultural dimensions (the sixth and seventh). These dimensions were the Indulgence vs. Restraint Index (IVR), and the Monumentalism Index (MON). All these dimensions are defined below:

- Power Distance Index (PDI) - The extent to which the less powerful members of institutions and organisations within a society expect and accept that power is distributed unequally.

- Individualism Index (IDV) - Individualism refers to a society in which the connections between individuals are loose while collectivism is the opposite of individualism, which stands for a society in which the connections between individuals are tight.

- Masculinity Index (MAS) - Masculinity stands for a society in which social gender roles are clearly different: men are supposed to be confident, strong, and focused on material success, while women are expected to be modest, kind, and focused on quality of life. Femininity is the opposite of masculinity. It stands for a society in which social gender roles overlap: both men and women are supposed to be modest, kind, and focused on the quality of life.

- Uncertainty Avoidance Index (UAI) - The extent to which the members of society feel uncomfortable or threatened by uncertain, unknown, ambiguous, or unstructured situations which lead them to support beliefs promising certainty and to maintain institutions protecting conformity.

- Long Term Orientation Index (LTO) - Long Term Orientation stands for a society which supports virtues oriented towards future rewards, in particular adaptation, perseverance and thrift. Short Term Orientation is the opposite; it stands for a society which supports 
virtues related to the past, in particular, respect for tradition, preservation of 'face', and satisfying social obligations.

- Indulgence vs. Restraint Index (IVR) - Indulgence stands for a society which allows relatively free gratification of some desires and feelings. Restraint is the opposite of indulgence, which stands for a society which regulates such gratification, and where people feel less able to enjoy their lives.

- Monumentalism Index (MON) - Monumentalism stands for a society which rewards people who are like monuments: proud and unchangeable. Self-Effacement is the opposite of monumentalism, which stands for a society which rewards humility and flexibility.

People from different cultural backgrounds have different ideas of how individuals observe, react and respond to activities that carry risks. This represents the cultural norms that individuals learn in their social environment, and it plays an important role in the way they behave (Fetscherin 2009). However, empirical studies on the impact of national culture on safety attitudes, behaviour and performance seem to be few and far between (Mearns \& Yule 2009). Mearns and Yule (2009) examined the extent to which Hofstede's dimensions of national culture are relevant to the study of safety climate and safety behaviour in a multinational construction, maintenance and facilities management company. Such differences in national culture could influence the efficacy of transferring safety processes and work systems from one country to another.

In the last few decades, a number of studies on Saudi national culture has been undertaken in different fields (Idris 2007). The first study by At-Twaijri (1989) investigated the comparison between Saudi and American managerial values. Also, Al-Meer (1989) compared Westerners, Asians, and Saudis concerning organisational commitment. AlMeer (1996) undertook another comparative study concerning the importance structure between Saudis and Westerners. Another study by Idris (2007) explored the cultural barriers to improved organisational performance in Saudi Arabia. In addition, Al-Gahtani, Hubona and Wang (2007) explored the impact of cultural differences on Information Technology (IT) acceptance.

\section{Safety Behaviour}

Safety behaviour is a component of safety performance (Neal, Griffin \& Hart 2000). Behaviour is defined as everything a person does that is visible and assessable (Vijayakumar 2007). Safety behaviour defines the behaviour that supports safety practices and activities that need to be accepted by employees according to occupational, safety and health requirements to avoid workplace accidents (Zin \& Ismail 2012). Safety behaviour in the workplace was first developed in 1930 after accident reports revealed that $95 \%$ of workplace accidents were caused by unsafe employee acts (Geller 2001). Subsequent research indicated that safety behaviour were influenced by organisational safety climate and safety culture (Clark 2006; Neal \& Griffin 2006), organisational safety commitment (Zohar 2002), and personality factors (Hinsz et al. 2007).

A study from Thailand by Jitwasinkul (2012) explored the role of organisational factors on safety behaviour of construction workers. The recommendation from this study is to conduct another study on influences of organisational factors on safety work behaviour in relation to different national cultures. Another study from a large petrochemical company in China revealed that the main causes of injury were a lack of safety training $(63 \%)$ and equipment failure (23\%). Thus, safety-related behaviour could be a key element in the prevention of accidents and deserves close attention. Petrochemical industry accidents are 
significantly associated with inadequate knowledge and unsafe behaviour of both employers and employees (Hong et al, 2004). Moreover, Salleh (2010) performed a comprehensive study regarding safety behaviour in the Malaysian petrochemical industry. The findings are encouraging in that they have been tested in relation to national culture within the same industry covered by this study_-petrochemicals.

\section{Method}

This study utilised quantitative method resulting from the research of well-established scholars in the field. A questionnaire survey was employed to identify the important national culture dimensions that influence safety behaviour of employees. The survey was used to collect the data for two constructs: national culture dimensions (NC); and safety behaviour (SB) measured with a five point Likert scale, ranging from 1 (strongly disagree) to 5 (strongly agree). Most of the questionnaire items adapted from the available published questionnaire instruments. The questionnaire for safety behaviour adopted from a study in the petrochemical industry performed by Salleh (2010) and national culture questionnaire used from Values Survey Module 2008 (VSM 08) by Hofstede et al. (2008). The questionnaire was distributed online via emails to managers and employees (web-based survey). The following section provides details of the results.

\section{Results}

An examination of the socio-demographic characteristics was presented in Table 1. The six socio-demographic characteristics used for this examination was: (1) age; (2) gender; (3) educational background; (4) work experience; (5) current position; and (6) nationality. The study population comprised of 407 (258 Saudi, 149 other nationality) managers and employees. All participants are males, and the participant's ages ranged from 20 to more than 59 years, with almost half of them (48\%) aged from 30 to 39 years. The educational background of the participants shows that almost half of the participants (48.6\%) had a Bachelor's degree. More than a quarter of the participants (36.4\%) had 6-10 years of work experience. The majority of the participants $(85.5 \%)$ had non-safety related position. The descriptive data analysis was performed using the SPSS program (version 21). In regard to national culture dimensions they were measured by four questions for each index and 12 questions for safety behaviour. Table 2 and 3 show the mean scores and the standard deviation for each variable.

Given the presence of significant number of non-Saudis responded to the survey, an independent sample t-test was conducted to compare the mean scores between Saudis and other nationalities to determine whether there is a significant difference between the data obtained from these two sample groups. A t-test for independent groups is useful when comparing the difference between the means of two groups with the same variable. Table 4 and 5 show that there are significant differences between Saudi and non-Saudi participants across many variables within both $\mathrm{NC}$ dimensions and SB construct. This indicates that the relationship between NC dimensions and SB should be analysed separately for each of the Saudi and non-Saudi sample groups.

Due to the significant differences of the NC dimensions and SB variables between the Saudi and non-Saudi samples, the dataset was separated into two. To ascertain the reliabilities of the survey items, the study utilised Cronbach's alpha $(\alpha)$ to determine how consistent the responses is across the items used in the survey questionnaire. Table 6 shows the values of the alpha coefficient of the NC and SB scales for the Saudi and non-Saudi samples. The alpha coefficients of the NC for both samples $(0.77$ and 0.78$)$ are considered 
good, whereas those of the SB for both samples (0.80 and 0.92$)$ are considered very good to excellent. These results indicate that the internal consistency of the NC and SB scales can be upheld in both Saudi and non-Saudi sample groups.

Table 2. Mean and SD of the National Culture (NC) items

\begin{tabular}{|c|c|c|}
\hline National culture dimensions & Mean & SD \\
\hline \multicolumn{3}{|l|}{ Power Distance Index (PDI) } \\
\hline Have a boss (direct superior) you can respect & 3.84 & 1.31 \\
\hline Be consulted by your boss in decisions involving your work. & 4.25 & 1.15 \\
\hline $\begin{array}{l}\text { An organisation structure in which certain subordinates have two } \\
\text { bosses should be avoided at all cost. }\end{array}$ & 2.91 & 1.12 \\
\hline $\begin{array}{l}\text { How often, in your experience, are subordinates afraid to contradict } \\
\text { their boss? }\end{array}$ & 3.28 & 1.17 \\
\hline \multicolumn{3}{|l|}{ Uncertainty Avoidance Index (UAI) } \\
\hline All in all, how would you describe your state of health these days? & 4.19 & .859 \\
\hline $\begin{array}{l}\text { A company's or organisation's rules should not be broken - not even } \\
\text { when the employee thinks breaking the rule would be in the } \\
\text { organisation's best interest. }\end{array}$ & 3.03 & 1.67 \\
\hline $\begin{array}{l}\text { One can be a good manager without having a precise answer to } \\
\text { every question that a subordinate may raise about his or her work. }\end{array}$ & 3.23 & 1.81 \\
\hline How often do you feel nervous or tense? & 2.83 & .845 \\
\hline \multicolumn{3}{|l|}{ Individualism Index (IDV) } \\
\hline Have security of employment. & 3.85 & 1.10 \\
\hline Have sufficient time for your personal or home life. & 3.77 & 1.52 \\
\hline Do work that is interesting. & 4.11 & 1.30 \\
\hline Have a job respected by your family and friends. & 4.30 & 1.34 \\
\hline \multicolumn{3}{|l|}{ Masculinity Index (MAS) } \\
\hline Get recognition for good performance. & 3.97 & 1.38 \\
\hline Have chances for promotion. & 3.68 & 1.73 \\
\hline Have pleasant people to work with. & 4.14 & 1.31 \\
\hline Live in a desirable area. & 4.29 & 1.32 \\
\hline \multicolumn{3}{|l|}{ Long Term Orientation Index (LTO) } \\
\hline Persistent efforts are the surest way to results. & 3.35 & 1.50 \\
\hline We should honour our heroes from the past. & 3.84 & 1.06 \\
\hline $\begin{array}{l}\text { If there is something expensive you really want to buy but you do } \\
\text { not have enough money, what do you do? }\end{array}$ & 3.26 & 1.22 \\
\hline Are you the same person at work and at home? & 3.40 & 1.60 \\
\hline \multicolumn{3}{|l|}{ Indulgence vs. Restraint Index (IVR) } \\
\hline Keeping time free for fun. & 3.47 & 1.65 \\
\hline Moderation: having few desires. & 3.74 & 1.64 \\
\hline Are you a happy person? & 2.48 & 1.30 \\
\hline $\begin{array}{l}\text { Do other people or circumstances ever prevent you from doing } \\
\text { what you really want to? }\end{array}$ & 3.06 & 1.01 \\
\hline \multicolumn{3}{|l|}{ Monumentalism Index (MON) } \\
\hline Modesty: looking small, not big. & 3.48 & 1.71 \\
\hline How important is religion in your life? & 3.68 & 1.46 \\
\hline Being generous to other people. & 3.11 & 1.54 \\
\hline How proud are you to be a citizen of your country? & 3.80 & 1.70 \\
\hline
\end{tabular}


Table 3. Mean and SD of the Safety Behaviour (SB) items

\begin{tabular}{lrr}
\hline Variable & Mean & \multicolumn{1}{c}{ SD } \\
\hline $\begin{array}{l}\text { I voluntarily carry out tasks or activities that help to improve } \\
\text { workplace safety. }\end{array}$ & 3.84 & 1.13 \\
$\begin{array}{l}\text { I help my colleague when they are working under risky or } \\
\text { hazardous conditions. }\end{array}$ & 3.94 & 1.17 \\
I often make suggestions to improve how safety is handled around & 3.97 & 1.00 \\
here (e.g. plant areas). & 4.03 & 1.15 \\
If I see something unsafe, I go out of my way to address it. & 4.18 & .98 \\
I am directly and/or indirectly involved in improving safety policy & & \\
and practices. & 4.19 & 1.02 \\
If I think it will make work safer, I initiate steps to improve work & 4.21 & .97 \\
procedures. & 4.27 & .75 \\
I ensure the highest levels of safety when I carry out my job. & 4.27 & 1.02 \\
I put in extra effort to improve the safety of the workplace. & 4.31 & .95 \\
I carry out my work in a safe manner. & 4.09 & 1.01 \\
I use the correct safety procedures for carrying out my job. & 4.36 & .936 \\
\hline I often try to solve problems in ways that reduce safety risks. & \\
I use all the necessary safety equipment to do my job. &
\end{tabular}

Table 4. Comparison between Saudi Arabian and other nationalities in terms of National Culture (NC) dimensions

\begin{tabular}{|c|c|c|c|c|}
\hline \multirow[b]{2}{*}{ National cultural dimensions } & \multicolumn{2}{|c|}{ Mean } & \multirow[t]{2}{*}{ T-Test } & \multirow[t]{2}{*}{ P-value } \\
\hline & $\begin{array}{l}\text { Saudi } \\
\text { Arabian }\end{array}$ & Others & & \\
\hline \multicolumn{5}{|l|}{ Power Distance Index (PDI) } \\
\hline Have a boss (direct superior) you can respect. & 3.82 & 3.89 & .524 & $.000 * * *$ \\
\hline $\begin{array}{l}\text { Be consulted by your boss in decisions } \\
\text { involving your work. }\end{array}$ & 4.25 & 4.23 & -.208 & .547 \\
\hline $\begin{array}{l}\text { An organisation structure in which certain } \\
\text { subordinates have two bosses should be } \\
\text { avoided at all cost. }\end{array}$ & 3.14 & 2.53 & -5.45 & .363 \\
\hline $\begin{array}{l}\text { How often, in your experience, are } \\
\text { subordinates afraid to contradict their boss? }\end{array}$ & 3.30 & 3.24 & -.346 & $.021 *$ \\
\hline \multicolumn{5}{|l|}{ Uncertainty Avoidance Index (UAI) } \\
\hline $\begin{array}{l}\text { All in all, how would you describe your state } \\
\text { of health these days? }\end{array}$ & 4.17 & 4.23 & .728 & .278 \\
\hline $\begin{array}{l}\text { A company's or organisation's rules should not } \\
\text { be broken - not even when the employee } \\
\text { thinks breaking the rule would be in the } \\
\text { organisation's best interest. }\end{array}$ & 3.38 & 2.43 & -5.73 & .140 \\
\hline $\begin{array}{l}\text { One can be a good manager without having a } \\
\text { precise answer to every question that a } \\
\text { subordinate may raise about his or her work. }\end{array}$ & 2.94 & 3.75 & 4.42 & $.003 *$ \\
\hline How often do you feel nervous or tense? & 2.84 & 2.82 & -.179 & .397 \\
\hline \multicolumn{5}{|l|}{ Individualism Index (IDV) } \\
\hline Have security of employment. & 3.62 & 4.23 & 5.50 & $.000 * * *$ \\
\hline Have sufficient time for your personal or home & 4.10 & 3.21 & -5.89 & $.001 * *$ \\
\hline
\end{tabular}




\begin{tabular}{|c|c|c|c|c|}
\hline \multicolumn{5}{|l|}{ life. } \\
\hline Do work that is interesting. & 4.06 & 4.18 & .881 & .251 \\
\hline $\begin{array}{l}\text { Have a job respected by your family and } \\
\text { friends. }\end{array}$ & 4.32 & 4.27 & -.363 & .854 \\
\hline \multicolumn{5}{|l|}{ Masculinity Index (MAS) } \\
\hline Get recognition for good performance. & 3.90 & 4.08 & 1.29 & .253 \\
\hline Have chances for promotion. & 3.47 & 4.04 & 3.26 & $.000 * * *$ \\
\hline Have pleasant people to work with. & 4.07 & 4.27 & 1.49 & .786 \\
\hline Live in a desirable area. & 4.40 & 4.09 & -2.31 & $.000 * * *$ \\
\hline \multicolumn{5}{|l|}{ Long Term Orientation Index (LTO) } \\
\hline Persistent efforts are the surest way to results. & 3.12 & 3.74 & 4.07 & $.000 * * *$ \\
\hline We should honour our heroes from the past. & 3.97 & 3.63 & -3.14 & .600 \\
\hline $\begin{array}{l}\text { want to buy but you do not have enough } \\
\text { money, what do you do? }\end{array}$ & 3.35 & 3.12 & -1.84 & $.014 *$ \\
\hline Are you the same person at work and at home? & 3.29 & 3.67 & 1.94 & .060 \\
\hline \multicolumn{5}{|c|}{ Indulgence vs. Restraint Index (IVR) } \\
\hline Keeping time free for fun. & 3.24 & 3.86 & 3.71 & $.002 *$ \\
\hline Moderation: having few desires. & 3.42 & 4.29 & 5.31 & $.000 * * *$ \\
\hline Are you a happy person? & 2.37 & 2.67 & 2.25 & $.000 * * *$ \\
\hline $\begin{array}{l}\text { Do other people or circumstances ever prevent } \\
\text { you from doing what you really want to? }\end{array}$ & 3.15 & 2.90 & -2.44 & .894 \\
\hline \multicolumn{5}{|l|}{ Monumentalism Index (MON) } \\
\hline Modesty: looking small, not big. & 3.41 & 3.61 & 1.17 & $.000 * * *$ \\
\hline How important is religion in your life? & 4.31 & 2.59 & -13.7 & $.000 * * *$ \\
\hline Being generous to other people. & 3.41 & 2.59 & -5.28 & $.000 * * *$ \\
\hline $\begin{array}{l}\text { How proud are you to be a citizen of your } \\
\text { country? }\end{array}$ & 3.49 & 4.34 & 4.99 & $.000 * * *$ \\
\hline \multicolumn{5}{|c|}{${ }^{*}$ Significant at $\mathrm{p}<0.05 ;{ }^{* *}$ Significant at $\mathrm{p}<0.01 ; * * *$ Significant at $\mathrm{p}<0.001$} \\
\hline \multicolumn{5}{|c|}{$\begin{array}{l}\text { Table 5. Comparison between Saudi Arabian and other nationalities in terms of Safety } \\
\text { Behaviour (SB) }\end{array}$} \\
\hline \multirow[t]{2}{*}{ Variables } & \multicolumn{2}{|c|}{ Mean } & \multirow[t]{2}{*}{ T-Test } & \multirow[t]{2}{*}{ P-value } \\
\hline & $\begin{array}{l}\text { Saudi } \\
\text { Arabian }\end{array}$ & Others & & \\
\hline $\begin{array}{l}\text { I voluntarily carry out tasks or activities that } \\
\text { help to improve workplace safety. }\end{array}$ & 4.06 & 3.44 & -5.46 & $.000 * * *$ \\
\hline $\begin{array}{l}\text { I help my colleague when they are working } \\
\text { under risky or hazardous conditions. }\end{array}$ & 3.99 & 3.85 & -1.10 & .218 \\
\hline $\begin{array}{l}\text { I often make suggestions to improve how } \\
\text { safety is handled around here (e.g. plant areas). }\end{array}$ & 4.09 & 3.77 & -3.14 & .174 \\
\hline $\begin{array}{l}\text { If I see something unsafe, I go out of my way } \\
\text { to address it. }\end{array}$ & 4.28 & 3.59 & -6.03 & $.000 * * *$ \\
\hline $\begin{array}{l}\text { I am directly and/or indirectly involved in } \\
\text { improving safety policy and practices. }\end{array}$ & 4.27 & 4.02 & -2.54 & .289 \\
\hline $\begin{array}{l}\text { If I think it will make work safer, I initiate } \\
\text { steps to improve work procedures. }\end{array}$ & 4.03 & 3.85 & -5.24 & $.000 * * *$ \\
\hline $\begin{array}{l}\text { I ensure the highest levels of safety when I } \\
\text { carry out my job. }\end{array}$ & 4.31 & 4.02 & -2.91 & $.023^{*}$ \\
\hline
\end{tabular}




\begin{tabular}{lllll}
\hline I put in extra effort to improve the safety of the & 4.31 & 4.20 & -1.40 & .361 \\
$\begin{array}{l}\text { workplace. } \\
\text { I carry out my work in a safe manner. }\end{array}$ & 4.25 & 3.90 & -5.69 & $.000^{* * *}$ \\
$\begin{array}{l}\text { I use the correct safety procedures for carrying } \\
\text { out my job. }\end{array}$ & 4.21 & 3.95 & -5.98 & $.000^{* * *}$ \\
$\begin{array}{l}\text { I often try to solve problems in ways that } \\
\text { reduce safety risks. }\end{array}$ & 4.10 & 4.08 & -1.17 & $.027^{*}$ \\
$\begin{array}{l}\text { I use all the necessary safety equipment to do } \\
\text { my job. }\end{array}$ & 4.29 & 4.08 & -4.71 & $.002^{*}$ \\
$*$ Significant at $\mathrm{p}<0.05 ; * *$ Significant at $\mathrm{p}<0.01 ; * * *$ Significant at $\mathrm{p}<0.001$ & & &
\end{tabular}

Table 6. Reliability coefficients

\begin{tabular}{ccccc}
\hline & $\begin{array}{c}\text { Number of } \\
\text { Items }\end{array}$ & $\alpha$ (Saudis) & $\alpha$ (Non-Saudis) & $\alpha$ (combined) \\
\hline NC & 28 & 0.77 & 0.78 & 0.77 \\
SB & 12 & 0.92 & 0.80 & 0.89 \\
\hline
\end{tabular}

Tables 7 summarises the Pearson's correlation (r) values between the NC dimensions and the SB construct of both the Saudi and non-Saudi samples. According to the table, SB of the Saudi sample is significantly correlated with IDV (individualism), MAS (Masculinity) and LTO (Long-term orientation). More specifically, the relationships between SB and both IDV and MAS is negative, indicating that higher levels of individualism and masculinity are linked with lower safety behaviour among Saudi workers. On the other hand, the positive relationship between LTO and SB within the Saudi sample indicates that the higher level of long-term orientation is associated with the higher level of safety behaviour.

For the non-Saudi sample, the only NC dimension that is significantly and positively correlated with SB is UAI (Uncertainty Avoidance Index). This suggests that only the higher level of uncertainty avoidance of the non-Saudi workers is associated with their increased level of safety behaviour.

Table 7. Pearson correlation between Safety behaviour (SB) and National Culture Dimensions (NC)

\begin{tabular}{lcccccccc}
\hline & SB & IDV & PDI & MAS & IVR & MON & UAI & LTO \\
\hline SB (Saudi) & 1 & $-.126^{*}$ & -.030 & $-.143^{*}$ & -.072 & .047 & .027 & $.124^{*}$ \\
& 1 & -.098 & .061 & -.071 & -.109 & .132 & $.263^{* *}$ & .051 \\
\hline
\end{tabular}

$* *$ Correlation is significant at $\mathrm{p}<0.01$ level (2-tailed)

*Correlation is significant at $\mathrm{p}<0.05$ level (2-tailed)

N.B. Correlation coefficients between NC dimensions are not shown.

While the above results require further in-depth analysis into the specific nature of the relationships between national culture and safety behaviour of both sample groups, they clearly highlight the need to acknowledge the different demographics of workforce within the Saudi petrochemical industry to ensure appropriate level of safety behaviour is maintained. It is apparent from the findings that the perceptions of the Saudi sample on their national culture differ to a significant extent from those of the non-Saudis. More importantly, such difference can be seen in the way in which specific dimensions of the 
national culture of these two distinct sample groups relate to the levels of safety behaviour. For management, the findings shed light on the need to appreciate and understand such cultural diversity among their employees and how it can be applied to help achieve superior safety management within the Saudi petrochemical industry.

\section{Conclusion}

In any workforce, ignoring cultural differences is a serious cause of misunderstandings and, as a result, conflict. All organisations function within a national cultural context, irrespective of whether that context is defined in terms of shared meanings, values and assumptions or observable rites and rituals. It is important to consider safety issues in the context of different cultural backgrounds. This study addressed this knowledge gap, within the context of the petrochemical industry in Saudi Arabia.

The results from the study presented in this paper show that there is a significant difference between the Saudi and non-Saudi employee groups in terms of the perceived national culture and safety behaviour. The difference between these two sample groups is also apparent in the relationships between specific national culture dimensions and the levels of safety behaviour. For the Saudi group, higher levels of masculinity and long-term orientation are associated with higher level of safety behaviour whereas higher level of individualism is associated with the lower level of safety behaviour. Only one national culture dimension, uncertainty avoidance, is shown to have a positive correlation with the level of safety behaviour of the non-Saudi sample. The finding highlights the need for managers to acknowledge the diversity among their employees and to understand how different attributes of national culture may have an impact on employees' safety behaviour. Future work is however required to further examine the nature of influence national culture has on safety behaviour.

\section{References}

Al-Gahtani, S.S., Hubona, G.S. and Wang, J., 2007. Information technology (IT) in Saudi Arabia: Culture and the acceptance and use of IT. Information \& Management, 44, 681-91.

Al-Meer, A., 1989. Organizational Commitment: A Comparison of Westerners, Asians, and Saudis. International Studies of Management \& Organization, 19 (2), 74-84.

Al-Meer, A., 1996. A Comparison of the Need Importance Structure between Saudis and Westerners. Journal of Management Development, 15 (5), 56-64.

At-Twaijri, M., 1989. A Cross-Cultural Comparison of American-Saudi Managerial Values in US-Related Firms in Saudi Arabia: an Empirical Investigation. International Studies of Management \& Organization, 19 (2), 58-73.

Bhaskaran, S. and Gligorovska, E., 2009. Influence of national culture on trans-national alliance relationships. Cross Cultural Management: An International Journal, 16 (1), 44-61.

Burke, M.J., Chan-Serafin, S., Salvador, R., Smith, A. and Sarpy, S.A., 2008. The role of national culture and organizational climate in safety training effectiveness. European Journal of Work and Organizational Psychology, 17 (1), 133-52.

Clark, S., 2006. The relationship between safety climate and safety performance: A Meta analytic review. Journal of Occupational health psychology, 11 (4), 315-27.

Cullen, W.D., 1980. HMSO. The Public Inquiry into the Piper Alpha Disaster. London: Her Majesty's Stationery Office.

Fetscherin, M., 2009. Importance of Cultural and Risk Aspects in Music Piracy: A crossnational Comparison among University Students. Journal of Electronic Commerce Research, 10 (1), 42-55. 
Finestone, N. and Snyman, R., 2005. Corporate South Africa: Making Multicultural Knowledge Sharing Work. Journal of Knowledge Management, 9 (3), 128-41.

Geller, E.S., 2001. The psychology of safety handbooks. Florida: Lewis Publisher.

Gordon, R.P.E., 1998. The contribution of human factors to accidents in the offshore oil industry. Reliability Engineering and System Safety, 61, 95-108.

Hinsz, V.B., Nickell, G.S. and Park, E.S., 2007. The role of Work Habits in the Motavation of Food Safety Behaviors. Journal of Experimantal Psychology, 13 (2), 105.

Hofstede, G., 1980. Culture's Consequences: International Differences in Work Related Values, Beverly Hills: Sage Publications, Inc.

Hofstede, G., 2001. Culture's Consequences: Comparing Values Behaviors, Institutions, and Organizations across Nations, Thousand Oaks, Calif: Sage Publications, Inc.

Hofstede, G. and Bond, M., 1988. The Confucius Connection: from Cultural Roots to Economic Growth. Organizational Dynamics, 16 (4), 5-21.

Hofstede, G., Hofstede, G., Minkov, M. and Vinken, H., 2008. Values Survey Module 2008 Handbook [online]. Available from: http://www.geerthofstede.n1/vsm-08/ [Accessed 12 August 2012].

Hong, Y.J., Lin, Y.H., Pai, H.H., Lai, Y.C. and Lee, I.N., 2004. Developing a Safety and Health Training Model for Petrochemical Workers. Kaohsiung J Med Sci, 20 (2), 56-61.

Idris, A., 2007. Cultural Barriers to Improved Organizational Performance in Saudi Arabia. SAM Advanced Management Journal, 72 (2), 36.

Jitwasinkul, B., 2012. Roles of Organizational Factors on Safety Work Behaviour of Construction Workers: A Bayesian Belief Network Approach. Thesis (PhD), Asian Institute of Technology, Thailand.

Mearns, K. and Yule, S., 2009. The role of national culture in determining safety performance: Challenges for the global oil and gas industry. Safety Science, 47, 777-85.

Neal, A. and Griffin, M.A., 2006. A Study of the lagged relationship among safety climate, safety motivation, safety behavior, and accidents at the individual and group Levels. Journal of Applied Psychology, 91 (4), 946-358.

Neal, A., Griffin, M.A. and Hart, P.M., 2000. The impact of organizational climate on safety climate and individual behavior. Safety Science, 34, 99-109.

Salleh, A., 2010. Safety Behavior in the Malaysian Petrochemical Industry. Thesis (PhD), Universiti Utara, Malaysia.

Schein, E., 1985. Organizational Culture and Leadership, Oxford: Jossey-Bass.

Vijayakumar, T., 2007. Achieve total Safety Culture through Behaviour Based Safety. In: 10th Conference and Exhibition of National Institute of Occupational Safety and Health (NIOSH), Malaysia, 303-13.

Wilpert, B., 1995. Psychology in high hazard systems-Contributions to safety and reliability. Invited Keynote Address given at the IV European Congress of Psychology, Athens.

Zin, S.M. and Ismail, F., 2012. Employers' Behavioural Safety Compliance Factors toward Occupational, Safety and Health Improvement in the Construction Industry. ProcediaSocial and Behavioral Sciences, 36, 742-51.

Zohar, D., 2002. Modifying Supervisory practice to improve subunit safety: A leadershipbased invention model. Journal of Applied Psychology, 87 (1), 156-63. 